\title{
Effects of different agro-climatic conditions on growth and yield performance of bari-2011 groundnut genotype
}

\author{
Saadullah Khan Leghari ${ }^{*}$, Abdullah Baloch ${ }^{2}$, Jahangir Ahmed ${ }^{3}$, \\ Mudassir Asrar Zaidi ${ }^{1}$, Muhammad Sabir Bangulzai ${ }^{4}$, Faisal Hussain ${ }^{5}$, \\ Muhammed Yaqoob ${ }^{6}$ and Nazir Ahmed \\ 1. Department of Botany University of Balochistan, Quetta-Pakistan \\ 2. Balochistan Agriculture Research \& Development Center Brewery Road, Quetta-Pakistan \\ 3. Agriculture Research Institute Sariab Quetta-Pakistan \\ 4. Government Inter College Brewery Road Quetta-Pakistan \\ 5. Department of Botany, Federal Urdu University of Arts, Science and Technology, Gulshan-e-Iqbal Campus, \\ Karachi-Pakistan \\ 6. Horticulture Research Institute (HRI)Khuzdar, Balochistan-Pakistan \\ 7. Agriculture Research Institute (ARI) Turbat kech-Pakistan \\ *Corresponding author's email: drsaadullahleghari@gmail.com
}

Citation

Saadullah Khan Leghari, Abdullah Baloch, Jahangir Ahmed, Mudassir Asrar Zaidi, Muhammad Sabir Bangulzai, Faisal Hussain, Muhammed Yaqoob and Nazir Ahmed.Effects of different agro-climatic conditions on growth and yield performance of bari-2011 groundnut genotype. Pure and Applied Biology. Vol. 6, Issue 1, pp53-59. http://dx.doi.org/10.19045/bspab.2016.50166

Received: $15 / 10 / 2016 \quad$ Revised: $14 / 12 / 2016$

Accepted: 18/12/2016

Online First: 21/12/2016

\section{Abstract}

The aim of this study was to evaluate the growth and yield performance of BARI-2011 groundnut variety at four different locations of Balochistan Provence, Pakistan viz: Quetta, Loralai, Panjgoor and Pishin under various agro-climatic conditions during dry summer season 2015. The study was carried out by a randomized complete block design (RCBD) method with four replications. Results showed that the significant differences were found for days to maturity, number of pods per plant, 20 pods length, 100kernals weight and dry pod yield $\mathrm{kg} \mathrm{ha}^{-1}$ among different locations. The crop matured earlier at Panjgoor with minimum days to maturity (152.75) as compared to the rest of the locations. The data for yield was ranged from 1061 to $2122 \mathrm{~kg} \mathrm{ha}^{-1}$. Bari 2011 showed maximum Dry pod yield (2122 kg ha-1), 100 kernels weight $(58.00 \mathrm{gm}), 20$ pods length $(70.25 \mathrm{~cm})$ and No of pods plant ${ }^{-1}(49.50)$ at Quetta that fallowed by Loralai and Panjgoor, respectively. The lowest dry pod yield $\left(1061 \mathrm{~kg} \mathrm{ha}^{-1}\right)$ was recorded at Pishin. The results indicated that BARI-2011 groundnut genotype showed highest dry pod yield $\mathrm{kg} \mathrm{ha}^{-1}$ at Quetta which fallowed by Loralai as compared to other locations, so it was concluded that the climate condition of Quetta and Loralai are best for BARI-2011 groundnut cultivation.

Keywords: Groundnut; Total yield; Climatic conditions; Balochistan; Pakistan

\section{Introduction}

In the world groundnut (Arachis hypogea L.) is considered the most important summer season economic crop. In Pakistan it grown-up in healthy drained sandy loam soil and in rain fed 
circumstances [1]. The crop is cultivated on 93 thousand hectares with annually production of 85 thousand tones [2]. Groundnuts is an important legume crop for the tropical and arid zoon farmers in Pakistan and its seeds contain high amounts of edible oil (43-55\%) and protein (25$28 \%$ ), with good foodstuff and feed crop [3]. Even though it is a fairly drought-tolerant, production and its production fluctuates considerably as a result of rainfall variability. Groundnut, being a drought tolerant high-income generating and environmental friendly crop, can be a substitute crop for Balochistan. A number of researchers investigated the productive potential of groundnut genotype under different agro-ecological zones. The significant differences for yield and its characteristic were noted in 12 groundnut genotypes at three locations of Malakand division, Pakistan [4]. Six groundnut genotypes at Lasbella, Balochistan, Pakistan evaluated and reported significant differences for yield within the year and over the years [5]. The groundnut variety $\mathrm{R}$ 8808 grown at five locations of karanatka, India and obtained $30 \%\left(1300 \mathrm{~kg} \mathrm{ha}^{-1}\right)$ more yield than check variety JL-24 (1000 kg ha $\left.{ }^{1}\right)$ [6]. Five high yielding groundnut genotypes were cultivated in eight different locations of Khyber Pakhtun Khwa (KPK), Pakistan during different seasons of 2003 at various altitude and heterogeneous soil [7]. They recorded significant differences for pod yield $\mathrm{kg} \mathrm{ha}^{-1}$, maturity period, mature kernel percentage, number of pods per plant and number of kernel per pod, among different locations and genotypes. The groundnut variety TAG-24 produced significantly highest pod yield $\left(2665 \mathrm{~kg} \mathrm{ha}^{-}\right.$ $\left.{ }^{1}\right)$ against the local check variety $(2032 \mathrm{~kg}$ $\mathrm{ha}^{-1}$ ) in 11 varieties trial at Mumbai, India [8]. Cross groundnut genotype (JL-24 X Co2) produced average pod yield of 1790 and $2060 \mathrm{~kg} \mathrm{ha}^{-1}$ under rain-fed and irrigated conditions, respectively at Uther Pradesh, India and the crop took 100-105 days to maturity [9]. Six different groundnuts genotypes included; BARI-2011, BARD479, PG-1102, PG-492, PG-1104 and Golden were investigated for agronomic stricture and yield stability at Quetta climatic condition during 2014 by Ahmed et al. [10]. They found that all the physiological parameters showed significant variation, the maximum yield potential (1653.3 kg ha-1) showed by BARI-2011 which fallowed by BARD-479 (1415.0 kg $\left.\mathrm{ha}^{-1}\right)$. This study was carried out to evaluate BARI-2011 high yielding (already screened at ARI, Quetta) groundnut genotype under diverse agro-climatic conditions of Balochistan, Pakistan (Quetta, Loralai, Panjgoor and Pishin) for commercial cultivation in the area.

\section{Materials and methods \\ Sites description}

Field experiments consisting of high yielding genotype BARI-2011 was evaluated under diverse climatic conditions of Balochistan, Pakistan viz; Quetta, Loralai, Panjgoor and Pishin (Table 2). The climate of first experiment area Quetta district was dry, arid: hot in summers and mild to extreme cold in winter. Quetta does not have a monsoon of sustained and heavy rainfall as it lies outside of monsoon range [11]. The climate of second experimental site Loralai district was dry but it varies with the elevation; at high altitude it was cold and dry, whereas, in the low altitude, especially in the south and east area (Tehsil Duki), temperature is uniform through the year, but hot in summer. According to the climate conditions the area can be distributed into semi-arid, sub-tropical and continental highlands. The winters are very cold and windy, whereas summers are mild [12]. The climate of third study area Panjgoor was warm in summer and cool in winters; terrain elevation ranging from 465 - 1776 meters 
above mean sea level. The potential evapotranspiration that doubly exceeds the precipitation, results in aridity or desertification. Summer is relatively shorter than winter. The rainfall is scarce in the area [13]. The climate of Pishin district can be classified as having delightful summers, dry and bitterly cold winters. Pishin lies outside the sphere of monsoon currents. The district experience storms in winter season. Rainy season is mostly in the months of December to April [14].

Table 2. Climatic data of investigated areas for the year 2014-15

\begin{tabular}{|l|l|l|l|l|l|l|l|l|}
\hline $\begin{array}{l}\text { Name of } \\
\text { Location }\end{array}$ & \multicolumn{5}{|c|}{ Temperature } & \multicolumn{5}{c|}{ Rainfall } \\
\hline & $\begin{array}{l}\text { Maximum } \\
\left({ }^{\circ} \mathbf{C}\right)\end{array}$ & $\begin{array}{l}\text { Mean of } \\
\text { Maxi }\end{array}$ & $\begin{array}{l}\text { Minimum } \\
\left({ }^{\circ} \mathbf{C}\right)\end{array}$ & $\begin{array}{l}\text { Mean of } \\
\text { Mini }\end{array}$ & $\begin{array}{l}\text { Maximum } \\
(\mathbf{m m})\end{array}$ & $\begin{array}{l}\text { Minimum } \\
(\mathbf{m m})\end{array}$ & Total & Mean \\
\hline Quetta & $40^{\circ} \mathrm{C}$ & $27^{\circ} \mathrm{C}$ & $-3^{\circ} \mathrm{C}$ & $9^{\circ} \mathrm{C}$ & $82 \mathrm{~mm}$ & $0 \mathrm{~mm}$ & $133 \mathrm{~mm}$ & $17.2 \mathrm{~mm}$ \\
\hline Loralai & $36.5^{\circ} \mathrm{C}$ & $22.3^{\circ} \mathrm{C}$ & $-1.5^{\circ} \mathrm{C}$ & $9.5^{\circ} \mathrm{C}$ & $58 \mathrm{~mm}$ & $0 \mathrm{~mm}$ & $98 \mathrm{~mm}$ & $13.4 \mathrm{~mm}$ \\
\hline Panjgoor & 44.3 & 33.5 & $5^{\circ} \mathrm{C}$ & $15^{\circ} \mathrm{C}$ & $26 \mathrm{~mm}$ & $0 \mathrm{~mm}$ & $76 \mathrm{~mm}$ & 6.3 \\
\hline Pishin & $36^{\circ} \mathrm{C}$ & $25^{\circ} \mathrm{C}$ & $-1^{\circ} \mathrm{C}$ & $8^{\circ} \mathrm{C}$ & $68.5 \mathrm{~mm}$ & $0.3 \mathrm{~mm}$ & $308 \mathrm{~mm}$ & $25.7 \mathrm{~mm}$ \\
\hline
\end{tabular}

\section{Soil characteristics}

The soil used for the experiments at all the investigated sites was similar in its characteristics. For maintaining soil condition $\mathrm{pH}$ and organic matter following parameters were done. Soils used in all the experimental areas were sandy loam in texture. The Soils $\mathrm{pH}$ and organic matter were maintained 7.8 and $56 \%$, respectively. The application of Randomized Completed Block design with four replications was made at each site and plot size was measured $4 \times 1.8 \mathrm{~m}$ with inter and intra rows space of $45 \mathrm{~cm}$ and $15 \mathrm{~cm}$, respectively. Fertilizers such as Urea, Nitophos and SOP were applied at the rate of $60,60,25$ NPK $\mathrm{kg} \mathrm{ha}^{-1}$, respectively as a basal dose diring soil preparation before the sowing of seeds at all the locations [10]. Gypsum @ $500 \mathrm{~kg}$ $\mathrm{ha}^{-1}$ was dusted on the standing crops at the time of full bloom for maximum pod set. $100 \mathrm{~kg} \mathrm{ha}^{-1}$ seeds (unshelled seed) were used for sown. The seeds were sown on May $10^{\text {th, }}$ 2015 at Quetta, on May $16^{\text {th }} 2015$ at Loralai, on May $20^{\text {th }} 2015$ at Pishin and $22^{\text {nd }}$ May 2015 at Panjgoor.

The recommended cultural and agronomic practices weeding, thinning, irrigation and protection measures spray of insecticide ripcord @ $2 \mathrm{ml} \mathrm{liter}^{-1}$ of water to control caterpillars, aphids and Nasoran @ 2.5 gm liter $^{-1}$ of water to control mites, were equally used to have a uniform crop and minimize the environmental variability's. Digging of pods was started at maturity. The randomly twenty selected plants from each plot were labeled and kept separately. The observations recorded for yield and yield components during the course of trial included: Days to maturity, Pods plant ${ }^{-1}, 20-$ pods length $(\mathrm{cm}), 100$-kernals weight $(\mathrm{g})$ and Pod yield $\left(\mathrm{kg} \mathrm{ha}^{-1}\right)$.

\section{Observations recording and analysis}

The method described by Khan et al. [15] was used for the counting of Days to maturity. The mature pods were considered when they showed dark brownish and yellow veins on inner side of shell with brownish yellow kernal testa. The best time for recording the maturity data was considered when the plant showed more than $60 \%$ growth of mature pods from the total [7]. Randomly 20-plants were selected from each plot for counting the number of pods per plant and on the average basis the number of pods plant-1 were recorded and counted. 100-kernels weight was measured as a seed size. It was considered the weight of 100 seeds from each plot in grams. 20plants were selected arbitrarily from each plant. For 20-pods length measurement the measuring scale was used. The pods of 
selected plants were positioned in vertical beside the measuring scale and measurement was done in centimeter. The methods described by Kham et al. [15] were used for recording the data about the yield of pods $\mathrm{kg}$ $\mathrm{ha}^{-1}$. From each plot the plants were harvested and then pods were dehydrated in sun and weighted for pod yield per sub plot. The yield was changed in to $\mathrm{kg} \mathrm{ha}^{-1}$ by means of following formula:

$$
\text { Pod yield }\left(\mathrm{kg} \mathrm{ha}^{-1}\right)=\left[\left(\operatorname{pod} \text { yield } \operatorname{plot}^{-1}(\mathrm{~kg}) / \text { plot size }\left(\mathrm{m}^{2}\right)\right] \times 10,000 \mathrm{~m}^{2}\right.
$$

\section{Statistical analysis}

Statistically the data was analyzed by the Analysis of Variance (ANOVA) [16] the consequences of differences among the means were compared by using Least Significant Difference (LSD) test [17].

\section{Results and discussion}

\section{Days to Maturity}

Results presented in Table 1 indicated that at all the investigated areas (Quetta, Loralai, Panjgoor and Pishin) BARI-2011 showed significant variations in their days of maturation. BARI-2011 significantly (p $\leq 0.05)$ matured earlier by 152.75 days at Panjgoor, while the maximum days taken to maturity at Quetta and Pishin was (163.5 days) and (162.25 days) respectively. However [10] during the study of Physiological response of different groundnut genotypes under semi-arid condition of Quetta Balochistan, Pakistan, reported that BARI-2011 was matured former (132.33 days) than others and the greatest days (161.0 days) were taken for maturity by the genotype PG-1104. Such variation in maturity of BARI-2011 may be due to different altitude. Moreover, soil heterogeneity also played an important role in maturity of the groundnut crop. The results of present study are in confirmation with the findings of $[7,9]$.

Table 1. Growth and yield performance of bari-2011 groundnut under different agroclimatic conditions of Balochistan

\begin{tabular}{|l|l|l|l|l|l|}
\hline $\begin{array}{l}\text { Locations } \\
\text { Name }\end{array}$ & $\begin{array}{l}\text { Days to } \\
\text { Maturity }\end{array}$ & $\begin{array}{l}\text { No of pods } \\
\text { plant }^{-1}\end{array}$ & $\begin{array}{l}\text { 20-pods } \\
\text { length }(\mathbf{c m})\end{array}$ & $\begin{array}{l}\text { 100-kernals } \\
\text { weight }(\mathbf{g m})\end{array}$ & $\begin{array}{l}\text { Dry pod yield kg } \\
\text { ha }^{-1}\end{array}$ \\
\hline Quetta & $163.50 \mathrm{~A}$ & $49.50 \mathrm{~A}$ & $70.25 \mathrm{~A}$ & $58.00 \mathrm{~A}$ & $2122.5 \mathrm{~A}$ \\
\hline Loralai & $157.25 \mathrm{~B}$ & $49.00 \mathrm{~A}$ & $65.25 \mathrm{~B}$ & $48.75 \mathrm{~B}$ & $2026.3 \mathrm{~A}$ \\
\hline Panjgoor & $152.75 \mathrm{C}$ & $41.00 \mathrm{~B}$ & $60.25 \mathrm{C}$ & $39.25 \mathrm{C}$ & $1510.0 \mathrm{~B}$ \\
\hline Pishin & $162.25 \mathrm{~A}$ & $39.25 \mathrm{~B}$ & $56.00 \mathrm{C}$ & $34.50 \mathrm{C}$ & $1061.3 \mathrm{C}$ \\
\hline Grand Mean & 158.94 & 44.688 & 62.938 & 45.125 & 1680.0 \\
\hline C.V & 1.48 & 3.95 & 4.30 & 7.15 & 4.07 \\
\hline LSD5\% & $\mathbf{1 . 6 5 9 4}$ & $\mathbf{1 . 2 4 8 6}$ & $\mathbf{1 . 9 1 5 8}$ & $\mathbf{2 . 2 8 2 2}$ & $\mathbf{4 8 . 3 1 9}$ \\
\hline
\end{tabular}

\section{Number of pods per plant}

Investigated areas showed significant differences $(p \leq 0.05)$ for their number of pods plant $^{-1}$ in BARI-2011, Significant highest number of pods plant ${ }^{-1}$ were reported at Loralai (49.5) which fallowed by Quetta (49), whereas the lowest number of pods plant $^{-1}$ was observed at Panjgoor (41) and Pishin (39.25) as presented in Table 1.
Similar results were also reported by other researchers [18] as they indicated the maximum number of pods (45) for BARI2011, followed by PG-1102 (42.3). Maximum number of pods per plant were also reported by Ahmed et al. [10] in BARI2011, which followed by genotypes groundnut PG-1102. This variation in pods plant $^{-1}$ in BARI-2011 from the present study 
may be due to the variation in soil characteristics and environmental factories. The variation in pod density among the present investigated locations might be due to climatic diversities (Table 2). Significant differences for pods plant ${ }^{-1}$, weight of 100kernel and total pod yield were also reported by other researchers $[4,8,15,19]$

\section{0-pods length $(\mathrm{cm})$}

Data presented in Table 1 for the length of 20-pods indicated a significant difference for BARI-2011, among the investigated locations. Results reported by Zamurrad et al. [18] also indicated significant variation for 20-pods length. In present investigated the highest 20-pods length were produced at Quetta $(70.25 \mathrm{~cm})$ which followed by Loralai $(65.25 \mathrm{~cm})$, whereas the lowest were recorded at Panjgoor $(60.25 \mathrm{~cm})$ and Pishin $(56 \mathrm{~cm})$. Similar results were also reported by Ahmed et al. [10], they found greatest 20-pods length $(75.0 \mathrm{~cm})$ in BARI-2011, which fallowed by BARD-479 $(72.0 \mathrm{~cm})$ and lowest was noted in PG-1104 (65.33 cm) 20-pods length. Whereas Zamurrad et al. [18] reported maximum 20-pods length $(72 \mathrm{~cm})$ for the varieties PG-1092 and BARI-2011, while check variety golden had minimum $(57 \mathrm{~cm})$ 20-pods length during his investigation for the performance based evaluation of ground-nut genotypes under medium rainfall condition of Chakwal. The variation in pod height/length may be attributed to specific climatic condition and genetic characteristics of the varieties. This variation could also be brought by changing in soil structure, texture, soil fertility and environmental condition [20].

\section{0-kernals weight (gm)}

Result about the weight of 100-kernels showed significant diversity $(\mathrm{p} \leq 0.05)$ among the experimental locations. Important diversity in 100-kernals weight was also indicated by Ahmed et al. [10]. In the present investigation the maximum 100kernal weight $(58 \mathrm{gm})$ was documented at
Quetta in BARI-2011 that followed by Loralai (48.75 gm), while the lowest 100kernals weight was recorded at Panjgoor (39.25 gm) and Pishin (34.5 gm) as presented in Table 1 . The observation reported by Ahmed et al. [10] also supported these results as they reported highest 100kernals weight in BARI-2011 which fallowed by BARD-479 at Quetta. However Zamurrad et al. [18] during their investigations reported maximum 100kernals weight in PG-1104 (63.3 g) which fallowed by BARI-2011 (60.7 g) while minimum was found in check variety Golden (47.3 g). This variation in 100kernals weight might be due to change in climatic condition. Present results were also accordance to the findings of other researcher [21]. They indicated significant variation in 100-kernals weight among different genotypes groundnuts and different climatic conditions.

\section{Dry pod yield kg ha-1}

Table I revealed that there were significant differences $(\mathrm{p} \leq 0.05)$ in the dry pod yield ha $^{-}$ 1 in BARI-2011 among the investigated locations. Ahmed et al. [10] also reported variation in dry pod yield of different groundnut genotypes. Present investigation exhibited maximum pod yield in BARI2011 at Quetta $\left(2122.5 \mathrm{~kg} \mathrm{ha}^{-1}\right)$, that fallowed by Loralai (2026.3 $\mathrm{kg} \mathrm{ha}^{-1}$ ) and Panjgoor (1510 kg ha $\left.{ }^{-1}\right)$. The minimum dry pod yield ha ${ }^{-1}$ was observed at Pishin (1061 $\left.\mathrm{kg} \mathrm{ha}^{-1}\right)$. Similar results were also noted by Zamurrad et al. [18] as they found that the genotype BARI-2011 had maximum pod yield (3648 $\mathrm{kg} \mathrm{ha}^{-1}$ ) while minimum pod yield $\left(2825 \mathrm{~kg} \mathrm{ha}^{-1}\right)$ was recorded for PG1104 , under medium rainfall conditions of Chakwal, these variation in productivity as compared to the present study might be due to change in climatic condition, soil characteristics and fertilizer concentration. Observation reported by Ahmed et al. [10] also supported the present results. In this 
investigation dry pod yield variation with in investigated locations might be due to climatic diversity at different areas. The variation in the dry pod yield at different locations was also reported by other investigators $[4,5,8,9,15,19,21-25]$.

\section{Conclusion}

On the basis of above results, it was concluded that the climate condition of Quetta and Loralai are best for BARI-2011 groundnut cultivation. BARI-2011 groundnut genotype showed highest dry pod yield $\mathrm{kg} \mathrm{ha}^{-1}$ at Quetta as compared to other locations. Therefore it is suggested that BARI-2011 groundnut genotype is suitable for commercial cultivation at Quetta and Loralai and it should avoided cultivating at Panjgoor and Pashin.

\section{Authors' Contributions}

Conceived and designed the experiments: SK Leghari, MA Zaidi \& J Ahmed, Performed the experiments: J Ahmed \& A Baloch, Analyzed the data: J Ahmed, SK Leghari \& F Hussain, Contributed reagents/ materials/ analysis tools: MS Bangulzai, M Yaqoob \& N Ahmed, Wrote the paper: SK Leghari \& J Ahmed.

\section{References}

1. Mensah JK \& Obadoni B (2007). Effects of sodium azide on yield parameters of groundnut (Arachis hypogaea L.). African Journal of Biotechnology 6(6): 668-671.

2. Anonymous (2010). Ministry of Food Agriculture and Livestock, Islamabad, Pakistan.

3. Din N, Mahmood A, Khattak GSS, Saeed I \& Hassan MF (2009). High yielding groundnut (Arachis hypogea L.) Variety "Golden". Pak J Bot 41(5): 2217-2222.

4. Khan A, Rahim M, Khan A \& Khan MI (2001). Yield response of groundnut genotypes under the sub-mountainous conditions of Malakand Division
(NWFP), Pakistan. Pak J Biol Sci 4 (4): 404-406

5. Taran SA, Haq MI, Baguti RA \& Taran $N$ (1998). Evaluation of groundnut varieties under irrigated condition in coastal area of Uthal, Baluchistan. Sarhad J Agric 14: 225-228.

6. Prakash BG, Sajjanar GM \& Naykar NY (1998). A promising groundnut variety, R8808, suitable for the northern dry zone of Karnataka. Int'l. Arachis Newslet 18: 8.

7. Khan N, Ullah $F$ \& Imtiaz Uddin $M$ (2009). Agronomic Characters of Groundnut Arachis Hypogaea Genotypes as affected by nitrogen and Phosphorus fertilization under rain fed condition. Electronic J Environ Agri \& Food Chem 8(1): 61-68.

8. Kale DM, Badigannavar AM \& Murty GS (1999). Groundnut variety TAG-24 with potential for wider adoptability. Int'l Arachis Newslet 19: 12-13.

9. Manoharan V, Ramalinggam RS, Vindhyavarman $\mathrm{P} \&$ Kalaimani $\mathrm{S}$ (1989). VRI-2: A new Spanish groundnut variety with drought resistance. Groundnut News 1: 3-4.

10. Ahmed J, Leghari SK, Asghar M, Baloch A, Danish MZ, Razaq A, Younas M \& Shah R (2016). Physiological response of different ground nut genotypes under semi-arid condition of Quetta Balochistan, Pakistan. Pure Appl Biol 5(2): 332338.

11. District profile of Quetta (2011). Profile of District. Development Quetta. Planning \& Development and Pakistan Social and Living Standards Measurement Survey.

12. District profile of Loralai (2011). Profile of District. Development Loralai. Planning \& Development and Pakistan Social and Living Standards Measurement Survey. 
13. District profile of Panjgoor, (2011). Profile of District. Development Panjgoor. Planning \& Development and Pakistan Social and Living Standards Measurement Survey.

14. District profile of Pishin, (2011). Profile of District. Development Pishin. Planning \& Development and Pakistan Social and Living Standards Measurement Survey.

15. Khan A, Bano A, Bakht J, Khan SA, Malik NJ \& Naz I (2009). Response of exotic Ground nut Genotypes to environmental diversities at higher altitude of Northern Pakistan. Sarhad J Agric 25(4): 545-550.

16. Gomez KA and Gomez AA (1984). Statistical procedures for Agricultural research. Wiley New York 680pp.

17. Steel RGD \& Torrie JH (1984). Principles and Procedures of Statistics. 2nd Ed. Mc Graw Hill Book Company, Singapore pp: 173-7.

18. Zamurrad M, Tariq M, Shah FH, Subhani A, Ijaz M, Iqbal MS \& Koukab M (2013). Performance Based Evaluation of Ground nut Genotypes under Medium Rainfall conditions of Chakwal J Agri - Food and Applied Sciences 1(1): 9- 12.

19. Khan A \& Rahim M. (1998). High yielding groundnut genotypes for the
North West Frontier Province, Pakistan. Int'l. Arachis Newslet 18: 1819.

20. Ahmed N \& Rahim M (2007). Evaluation of promising ground nut (Arachis hypogees L.) varieties for yield and other characters. J Agric Res 45(3): $185-189$.

21. Shukla AK \& Rai PK (2014). Evaluation of ground nut genotypes for yield and quality traits. Annals of Plant and Soil Research 16(1): 41 - 44.

22. Khan A (2005). Physiological response of groundnut to growth regulators under drought stress. Ph. D Dissert. Deptt. of Biology. Sci. Quaid-e-Azam Univ. Islamabad, Pakistan.

23. Khan A, Bakht J, Bano A \& Malik NJ (2012). Response of Groundnut (Arachis hypogaea L.) Genotypes to Plant Growth Regulators and Drought Stress. Pak J Bot 44(3): 861-865.

24. Rajeshwari (1998). Evaluation of groundnut genotype for rainfed conditions in the northern coastal zone of Andhra Pradesh, India. Int'l Arachis Newslet 19:13-15.

25. Gao L, Jiang Z, Long B, Feng F \& Deng F (1996). Breeding an early and high yielding groundnut variety Nonghua 22 in China. Int'l. Arachis Newslet 16: 8-9. 